\title{
Impact of Performance Feedback for Effective Use of Digital Badges
}

\author{
Erin D. Besser ${ }^{1} \&$ Timothy J. Newby ${ }^{2}$ \\ ${ }^{1}$ College of Education, California State University Fullerton, Fullerton, California, USA \\ ${ }^{2}$ College of Education, Purdue University, West Lafayette, Indiana, USA \\ Correspondence: Erin D. Besser, College of Education, California State University Fullerton, Fullerton, \\ California, USA. E-mail: ebesser@fullerton.edu
}

Received: March 10, 2020 Accepted: April 30, 2020 Online Published: May 15, 2020

doi:10.5539/jel.v9n3p79 URL: https://doi.org/10.5539/jel.v9n3p79

\begin{abstract}
A recent educational trend has been the increasing focus on validating and credentialing learning taking place outside of traditional academic settings. Digital badges have the potential to address various concerns within formal education settings. Digital badges have been heralded for having the ability to show mastery of content, and more accurately reflect the actual knowledge and skills of learners (Mehta, Hull, Young, \& Stoller, 2013). Digital badges have been shown to increase motivation (Light \& Pierson, 2014; Lin et al., 2013), increased student learning outcomes (Newby \& Cheng, 2019; Wonder-McDowell et al., 2011), and overall comprehensiveness of learning (Mettler, Massey, \& Kellman, 2011). Formative assessment through instructor feedback is crucial to mastering content and displaying achievement. Feedback delivers important information regarding desired learning and perceived learning and affords opportunities to decrease that gap. A common misconception is that all digital badges are automated, however, in many teaching and learning settings, feedback is provided by instructors. The authors provide a set of optimal feedback suggestions to aid in Mastery Learning and digital badge instruction and consider the implications these actions in education.
\end{abstract}

Keywords: digital badges, instructor feedback, mastery learning

\section{Introduction}

A recent educational trend has been the increasing focus on validating and credentialing learning taking place outside of traditional academic settings. There has been growing interest in the concept of digital badges. Mozilla's Open Badges program was one of the first organizations to apply this system digitally to learning within a variety of contexts. Mozilla (n.d.) notes the purpose of digital badges is to recognize and share learning. The MacArthur Foundation (2014) further defines digital badges as, "An assessment and credentialing mechanism that is housed and managed online. Badges are designed to make visible and validate learning in both formal and informal settings and hold the potential to help transform where and how learning is valued" (n.p.). Digital badges are a visual representation of learning and skills (Figure 1).
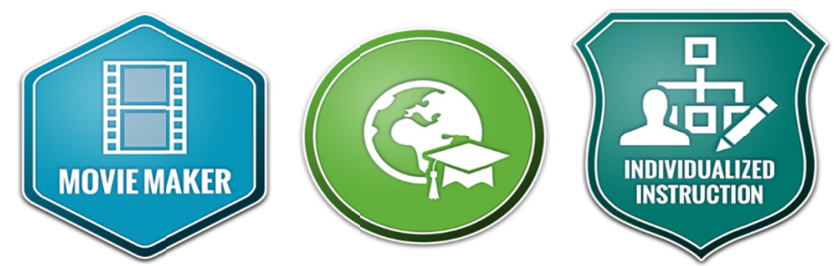

Figure 1. Digital badges for teaching and learning

Digital badge platforms provide learners with a space in which to not only earn badges but to display their accomplishments. Developers not only create a unique icon for learners to display but a set of specific standards and criteria the learner must meet in order to be awarded the badge. Awarded badges can then be displayed in a variety of places: personal web pages, social media, resumes, and other digital settings. Figure 2 depicts Mozilla's Open Badge program (n.d.) and how the system works to recognize formal and informal learning experiences. 


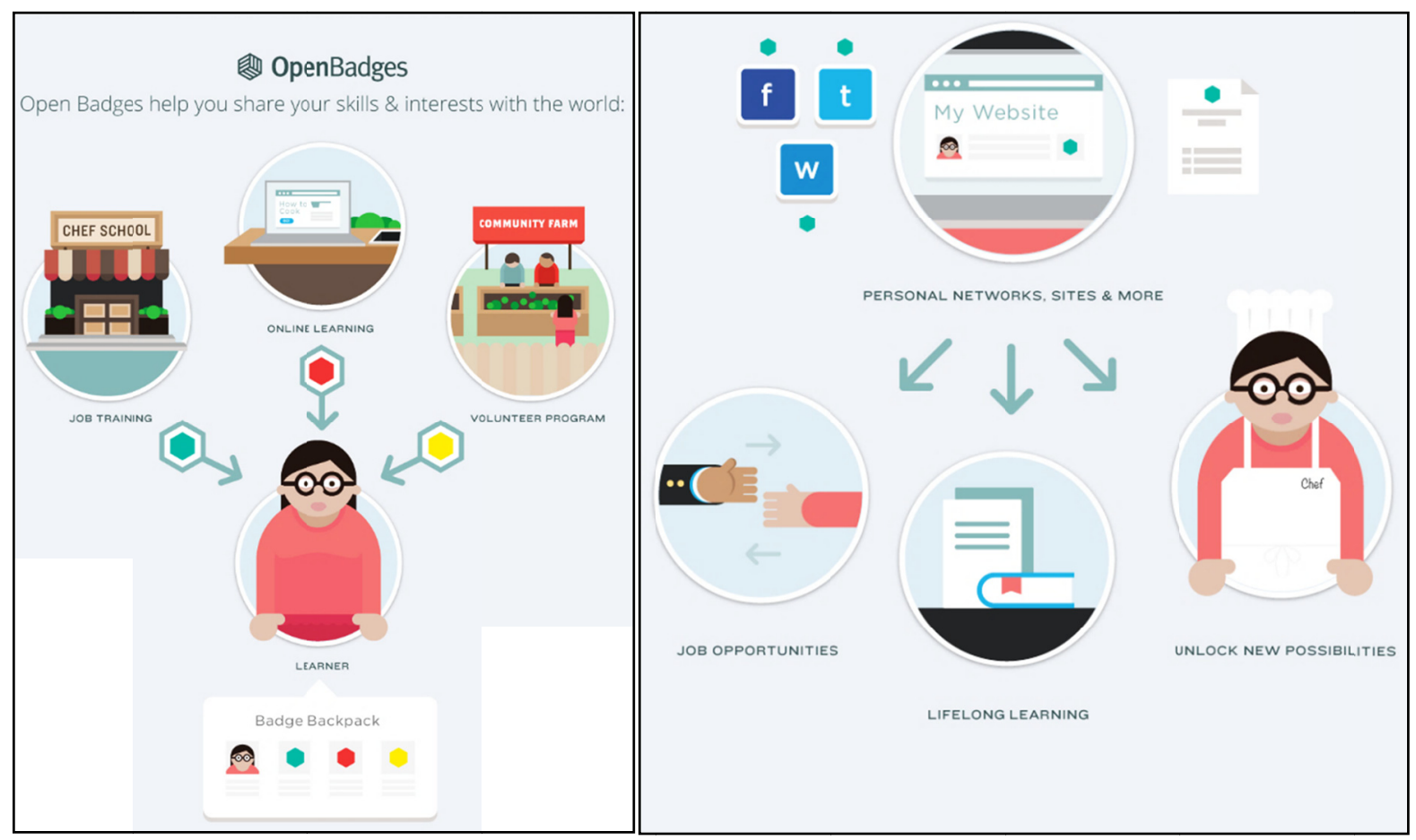

Figure 2. How Mozilla’s Open Badges work (Mozilla, n.d.).

The term digital badge refers to a representation of skills or knowledge earned by the individual; Open Badges are also used in the literature. Knight et al. (2014) set forth several distinct differences corresponding to this term and specifically to Mozilla's unique badges. Open badges are free (software is open for everyone to use), transferable (badges can be collected from multiple outlets and displayed in a single source), stackable (badges display a progression of skills and knowledge), and evidence-based (criteria and evidence are linked to each badge). The definition of Open Badges does differ based on various stakeholders' perspectives. Devedžić and Jovanović (2015) identify these perspectives as learner-centered, teacher-centered, institutional, Schools', and Employers'. While Open Badges does refer to Mozilla's digital badge project, within the literature the definitions (e.g., open badge, digital badge, badge) are being used interchangeably.

\section{Digital Badge Use in Higher Edcuation}

While Mozilla and other organizations are proliferating badges for recognizing accomplishments and learning outside of formal academic settings, universities and schools alike are applying the concept to reinvent traditional education. At the same time not, all badges are alike. Badges have been described as, "a common currency to denote learning outcomes and give employers a visual representation and evidence of an applicant's skills" (Bowen \& Thomas, 2014, p. 22). Digital badges have the potential to address various concerns within formal education settings. Buckingham (2014) has identified three challenges that plague the education system and how these challenges can be addressed by badges. First, he notes many soft skills (e.g., team building, communication) are undervalued in formal educational settings. Digital badges that specifically address acquiring these skills can be earned and awarded. Next, there is a challenge of how to encourage participants to maintain a high standard of work ethic while participating in voluntary activities. Digital badges can be earned and awarded for high-level work that is completed on the learner's own time. Lastly, Buckingham addresses the challenge of promoting self-regulated and directed learning. Digital badges in conjunction with a community specialist and/or mentor can aid learners in progressing through the learning process. In one study, researchers looked at the benefits of Digital badges with regards to motivation theory (Abramovich, Schunn, \& Higashi, 2013). While the results indicated increased interest, increased expectations, and both positive and negative effects on learning, they also noted the importance of providing learners with details on how to earn the badge (e.g., actions or behaviors that are necessary).

As formal education settings begin to discover how Digital badges apply to their specific content and program areas, Gibson (2013) notes how this system can inform formal education in a way that produces students with a 
more complete understanding of their professional field.

A badge can be a pointer or reference to a process by which a learner engages in and receives validation from a community that practices authentic assessment. A badge can also represent a guide for students who are seeking direction and can provide transparency and motivation for moving from the periphery of a community to its core. Ideally, a badge can celebrate not just the accomplishment of co-discovered goals, but the engagement of the community in assessing and guiding the progress of the learner (p. 461).

Digital badges have the potential to give students a more holistic view of their future profession by incorporating formal and informal learning experiences as well as giving them opportunities to network and receive mentorship from professionals in their field.

In academic settings where Digital badges are taking over conventional task formats, instructional designers are faced with the challenge of how to deliver and assess content and skills within badges. While many Digital badges have automated award systems through the passing of online quizzes or completing required materials, in many cases there are content experts behind each badge. Digital badges have been heralded for having the ability to show mastery of content, and more accurately reflect the actual knowledge and skills of learners (Mehta, Hull, Young, \& Stoller, 2013).

\section{Digital Badges and Mastery Learning}

Digital badge systems pair well with Mastery Learning because of the need to meet a specific set of objectives and criteria. Giving students opportunities to work at their own pace and demonstrate mastery of knowledge is rewarded within the badge system, while also communicating deep learning. It is through these rewards (Digital badges) that students are able to display their knowledge for the world to see, appealing to professionals in their fields (Randall, Harrison, \& West, 2013). Pairing Digital badges with Mastery Learning has the potential to produce similar results to studies without Digital badge technology, like increased motivation and engagement among students (Light \& Pierson, 2014; Lin et al., 2013) and increased student learning outcomes (Newby \& Cheng, 2019; Wonder-McDowell et al., 2011). While badges themselves are not necessarily assessment, they depict that assessment has taken place and the criteria that were needed to get there was accomplished (Ostashewski \& Reid, 2015). Systems like Passport (Tally, 2012) offer capabilities that assist feedback practice. These systems have the potential to increase student learning (Higgins et al., 2002), the quality of learning (Lynch et al., 2012), and critical thinking (Lynch et al., 2012). Instructors are able to give an assessment, while students are able to display that assessment (through awarded badges) all within one platform. The process of receiving and applying feedback is not only essential in Mastery Learning contexts but within Digital badges systems. Detecting students' gap in knowledge is required in receiving digital badge achievements.

Additionally, within digital badges systems students are able to be the creators of their own educational experiences.

Allowing students to choose the pathways they will follow to achieve learning goals is necessary for self-regulated learning and an increased sense of self-efficacy. The practice of allowing students to choose instructional activities that are aligned with their unique learning styles, academic strengths, and interests further contributes to learner self-efficacy (Bangert, 2004).

Bloom (1968) notes that in traditional contexts students receive virtually the same instruction, but it is the student's aptitude that varies. In traditional contexts, the time students have to learn is fixed resulting in varied knowledge. Within the mastery model, time is fluid and the instruction is fixed. Instructors not only allow learners to work at their own pace but provide varied levels of scaffolding to aid in the mastery of the content (Reigeluth \& Karnopp, 2013). For example, Slavin and Karweit (1984) applied the mastery model to math content individually versus within a team. As the team progressed, students completed assignments at varying times. Incorporating extension activities allows learners with quicker pace opportunities to deepen their knowledge, while students working at a slower pace were given the correctives they needed. In a later publication, Bloom (1976) emphasized the change in time to master content shifts as learners master fundamental knowledge. Additionally, learners may have a need for more mentorship as they wade through foundational materials that fade as the learners become more proficient. Guskey (2007) has identified instructional feedback as fundamental to supporting student learning in content mastery. He emphasizes the importance of not only frequent feedback but specific feedback. In addition to providing feedback, instructors must "pair with correctives: activities that offer guidance and direction to students on how to remedy their learning problems" (p. 16). Slavin and Karweit (1984) echo this sentiment in asserting that correctives bring about a new perspective, one that differs from the initial teaching while differentiating guidance for each individual student. The aim is to clear up misconceptions and address small errors. 
Bloom (1971a) identified three major components of teaching and learning: 1) the learning goals and objectives are clearly defined; 2) instruction that results in mastery, and 3) feedback and correctives are necessary to facilitate mastery. All three of these components must be aligned in order for students to achieve mastery. Not only is aligning learning goals and objectives to instructional methods important in regard to formal assessment such as standardized testing, but it also has been linked to increased student achievement (Squires, 2012). Guskey (2007) also adds that instructors must be versed enough with the content that they can designate the evidence that is necessary to display that the learning goals and objectives have been met.

In current Higher Education contexts, instructors and institutions alike are looking for ways to equip students with knowledge for the global workforce. As students embark in a rapidly changing workforce, they need to have abilities to transfer knowledge to contexts that are continuously evolving. Institutions and instructors are employing strategies, such as digital badges, that aid in students' abilities to do such a thing. Emerging technologies allow us to reimagine Mastery Learning and leverage them in ways that can make implementing this instructional approach easier for the instructor and more beneficial to the learner. Specifically, the uses of adaptive technologies are being incorporated into Mastery Learning contexts. Adaptive technologies refer to:

Two main points: 1) sequence of instructional actions taken by the program varied as a function of a given student's performance history, and 2) the program is organized to modify itself automatically as more students complete the course and their response records identify defects in instructional strategies (Atkinson, 1974, p. 336).

Use of these kinds of technologies has been shown to increase achievement, overall comprehensiveness of learning, and increased fluency in learning (Mettler, Massey, \& Kellman, 2011). While these systems are not always incorporated, they do offer a key point regarding the individualized nature of Mastery Learning contexts and how digital badge technology might be used to enhance this instructional model.

Leveraging technology is one way in which Mastery Learning might be enhanced. When we look to digital badges we see overlap among the Mastery Learning model: learners want to master content (Mehta et al., 2013), time is fluid and criteria is static (Reigeluth \& Karnopp, 2013), mentorship and instructor support is crucial (Bloom, 1976; Guskey, 2007), and motivation and engagement are increased (Abramovich et al., 2013; Glover \& Latif, 2013). In many mainstream outlets, we see the intersection of Mastery Learning and game-based design within digital badges. For example, Khan Academy delivers content through short videos that allow students to revisit material and receive supplemental activities to either correct or enrich. Furthermore, users are given digital badges for achievements in learning and completion.

As instructors begin to incorporate digital badges within formal educational settings, using a Mastery model seems to be a natural place to start. For example, Carnegie-Mellon University (CS2N, n.d.) is implementing badges within their computer science programs (CS2N). Incorporating Digital badges and Mastery Learning can be challenging within the confines of traditional education. This instructional approach is providing instructors a set of guidelines to not only help their students' master content but also to give them greater direction in how to help them get there. Formative assessment through instructor feedback is crucial to mastering content and displaying achievement.

\section{Instructional Feedback}

Researchers (Bloom, 1968; Guskey, 2007; Kluger \& DeNisi, 1996; Slavin \& Karweit, 1984) agreed feedback is a critical part of formative assessment and is a crucial component of Mastery Learning. Yorke (2003) concludes, "The central purpose of formative assessment is to contribute to student learning through the provision of information about performance" (p. 478). Instructors provide feedback to students as a way to inform them of their processes, to guide and mentor students, and to inform their own teaching. Black and Wiliam (1998) emphasize the interactions between teachers and students, and student's peer interactions Moreover, they emphasize how feedback plays a part in crafting instructional learning interactions: "All such work involves some degree of feedback between those taught and the teacher, and this is entailed in the quality of their interactions which is at the heart of pedagogy" (p. 7).

Various definitions of feedback can be found throughout the literature. Kulhavy (1977) specifies feedback as a set of procedures used to inform the learner, whereas Ramaprasad (1983) defines feedback as the gap between ideal and actual achievement. Tucker (1993) highlights the importance of feedback when evaluating dynamic instructional programs because it's "presence or absence can dramatically affect the accuracy required of human judgment and decision making" (p. 303). Additionally, some authors have begun to try to establish a set of broad purposes or roles. Price et al. (2010) have defined five categories of feedback: correction, reinforcement, forensic diagnosis, benchmarking and longitudinal development (feed-forward). While there have been developments in 
the role technology plays in automating the feedback process (Azevedo \& Bernard, 1995) more often feedback falls on the shoulders of an instructor.

Best teaching practices offer educators and teacher education programs a set of guiding principles as they wade through their course instruction. These guidelines, however, are not a magic bullet; educators still must contend with varying curricula, instructional approaches, student characteristics, and academic personnel and support. What best practices do is identify areas of importance and give educators a place to start when critically examining their instructional approaches. The set of principles offered by Chickering and Ehrmann (1996) and Chickering and Gamson (1989) have been a source of guidance for a variety of educational contents. A common thread running through the Seven Principles of Good Practice is the impact feedback has on each principle. While Chickering and Gamson (1987) limit feedback to its own category, it is not independent of itself. Feedback radiates throughout each principle, and in many cases is crucial to the overall success of that principle. For example, cooperation and learning collaboratively have the power to clear up misconceptions and to afford students opportunities to share and negotiate their own thoughts and ideas. Without specific feedback to guide these interactions, students could be left worse off than without these experiences. Feedback, consequently, allows each principle to be most effective and gives students and instructors opportunities to maximize the impact the principle has within learning. In a study regarding peer and self-feedback among preservice teachers, researchers found feedback was shown to develop preservice teachers' critical thinking skills and resulted in an increased quality of learning results (Lynch, McNamara, \& Seery, 2012). In a similar study on the impact of feedback within a modular higher education degree program, researchers found feedback to have the potential to improve student learning (Higgins, Hartley, \& Skelton, 2002). In addition to improving learning outcomes, students desire written feedback (Getzlaf, Perry, Toffner, Lamarche, \& Edwards, 2009; Hmelo-Silver \& Barrows, 2006). They want to read their instructor's comments and hear their thoughts and opinions. Furthermore, students expect that feedback and the effort put into the task are mutually exclusive (Higgins et al., 2002). Students believe the effort and time they put into an assignment should result in the same effort and time within assessment and feedback. The role feedback plays in the learning process is significant, but what is even more essential is the nature of the feedback that is being provided by instructors.

Chickering and Gamson (1987) posit that the Seven Principles promote activity, interaction, cooperation, diversity, responsibility, and expectations within teaching and learning. These "forces" (p. 3) could be considered precursors to today's $21^{\text {st }}$-century skills: analytical thinking, creativity, collaboration, communication, problem-solving (Skills, 2009) because their aim is developing students with skills, knowledge, and expertise required for the modern world. Combining Chickering and Gamson's (1987) Seven Principles and 21 ${ }^{\text {st }}$-century skills gives educators an even greater framework in which to support their instruction. Additionally, using technology in conjunction with these principles affords educators opportunities to be more efficient and purposeful in their instructional decisions, while still including many of the principles of good practice. Bangert (2004) reinforces this sentiment specifically when thinking about online instruction:

Authentic instructional activities that include simulations, case-based examples, and other problem-solving exercises not only increase interactive learning but also support the principle of high expectations. Clear performance expectations that accompany authentic instructional activities inform students of the criteria necessary for demonstrating acceptable and proficient levels of performance (p. 218).

Graham et al. (2001) and Bangert (2004) used the principles as a framework for evaluating online instruction. Thurmond, Wambach, Connors, and Frey (2002) suggested the principles promote overall active learning. Martyn (2007) went a step further by connecting the principles to active learning in her study integrating the use of technology within undergraduate course activities.

\subsection{Characteristics of Feedback}

Both Balzer et al. (1989) and Butler and Winne (1995) discuss the functions feedback plays within learning, with Butler and Winne (1995) building upon Balzer et al.'s (1989) work. Table 1 provides a brief description of these topics. 
Table 1. Functions of feedback

\begin{tabular}{|c|c|c|c|c|}
\hline Function & \multicolumn{3}{|l|}{ Description } & Example \\
\hline $\begin{array}{l}\text { Outcome } \\
\text { Feedback }\end{array}$ & \multicolumn{3}{|c|}{ Simple, indicates results about performance, no information regarding the } & "Correct", "Incorrect" \\
\hline \multirow[t]{3}{*}{$\begin{array}{l}\text { Cognitive } \\
\text { Feedback }\end{array}$} & $\begin{array}{l}\text { Elaborate, cues are tied } \\
\text { to performance and task }\end{array}$ & Task validity & $\begin{array}{l}\text { Observer's perception of } \\
\text { the relationship between } \\
\text { cues and achievement }\end{array}$ & $\begin{array}{l}\text { "Remember the video you were to watch } \\
\text { on } 21^{\text {st }} \text {-century skills? If you had } \\
\text { referenced the points made in that video, } \\
\text { you would have understood } 21^{\text {st }} \text {-century } \\
\text { skills better" }\end{array}$ \\
\hline & & Cognitive validity & $\begin{array}{l}\text { The Learner's perception } \\
\text { of the relationship } \\
\text { cues and achi and }\end{array}$ & $\begin{array}{l}\text { Prompted after reviewing the material: } \\
\text { "Did you remember to watch the video } \\
\text { on } 21^{\text {st }} \text {-century skills? If not make sure } \\
\text { you do so and pay attention to the main } \\
\text { points." }\end{array}$ \\
\hline & & Functional validity & $\begin{array}{l}\text { Relationship between the } \\
\text { learners' estimate } \\
\text { achievements and actual } \\
\text { achievements }\end{array}$ & $\begin{array}{l}\text { After reviewing required materials } \\
\text { students might be presented with a quiz. } \\
\text { Upon completion: "based on your score } \\
\text { your understanding of } 21^{\text {st }} \text {-century skills } \\
\text { is } 40 \% \text {." }\end{array}$ \\
\hline
\end{tabular}

The work presented by Balzer et al. (1989) and Butler and Winne (1995) explores the types of feedback instructors may provide to students. Whereas Yang and Carless (2013) argue that content plays a specific role in the nature of feedback. They offer a framework focusing on three distinct dimensions of feedback: cognitive, social-affective, and structural. The Feedback Triangle (Figure 3) shows an interplay of each dimension where each comes together in the feedback space. Both the cognitive and social-affective categories reflect areas that pertain to the student and teacher, whereas the structural dimension refers to actions that are often outside of their control (e.g., administration, policy, technology restrictive).

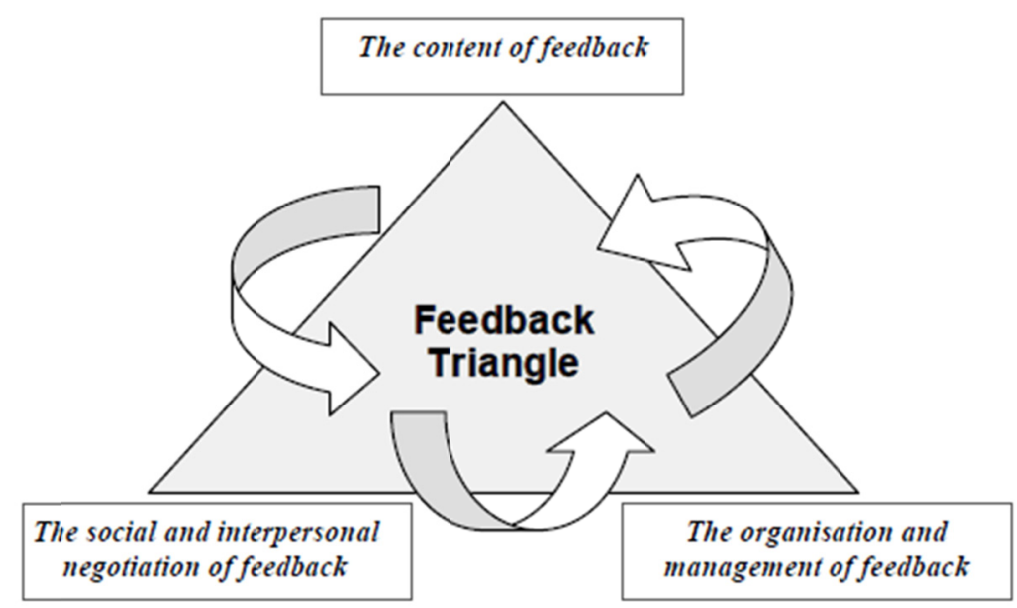

Figure 3. The feedback triangle (Yang \& Carless, 2013)

The cognitive dimension focuses on the content. In addition to the academic knowledge, this dimension also refers to the underlying "beliefs, values, concepts and principles, as well as methodologies and skills for investigating disciplinary problems and practices in the profession" (Yang \& Carless, 2013, p. 288). Specifically, this dimension requires students to know the academic content, but also how to apply feedback in a way that lessens the gap in achievement.

This dimension relates to "how feedback implies messages about students' social role in their learning environment, and how students' emotions are engaged as they undertake learning and assessment tasks" (Yang \& Carless, 2013, p. 289). Specifically, in this dimension, the emotional well-being and interactions play a role in how well the learner receives feedback and is then able to apply it. Relationships between instructor and student are an important factor and directly connects to Chickering and Ehrmann (1996) and Chickering and Gamson's 
$(1987,1989)$ principle of student-faculty interaction.

Within the organizational dimension "structural constraints are a major barrier facing effective feedback processes and arise from assessment policies, practices and the ways universities are organized" (Yang \& Carless, 2013, p. 292). The restrictions that are often in place regarding feedback result in the need for flexible systems that give instructors options for elaboration and for providing timely responses. The organizational dimension can be enhanced through the use of technology tools. Video and audio feedback can reduce the time it takes for instructors to produce elaborate answers. Tools like Digital badges provide opportunities for instructors to give feedback to students built within the systems.

The characteristics of feedback brought forth through The Functions of Feedback (Balzer et al., 1989; Butler \& Winne, 1995) and the contextual considerations provided by The Feedback Triangle (Yang \& Carless, 2013) give instructors a general idea of the nature of feedback, but do not provide practical application of current research. Nicol and Macfarlane-Dick (2006) appeal to the practitioner directly connecting the Seven Principles of Good Practice (Chickering \& Gamson, 1987) to feedback in their model. Table 2 provides a summary of Nicol and Macfarlane-Dick's (2006) model of Principles of Good Feedback Practice.

Table 2. Principles of Good Feedback Practice

\begin{tabular}{|c|c|c|c|}
\hline Principle & Description & Implementation & Example \\
\hline $\begin{array}{l}\text { Clarify in } \\
\text { performance }\end{array}$ & $\begin{array}{l}\text { Feedback helps to clarify what } \\
\text { good performance is and } \\
\text { communicates the goals, } \\
\text { criteria, and expectations of the } \\
\text { task. }\end{array}$ & $\begin{array}{l}\text { LMS's provide a repository for } \\
\text { written criteria. } \\
\text { Digital badge systems give students } \\
\text { criteria and a place to complete the } \\
\text { task within a single system. }\end{array}$ & $\begin{array}{l}\text { "Consider reviewing the objectives on } \\
\text { page } 1 . \text { Use these objectives to guide } \\
\text { your essay writing." }\end{array}$ \\
\hline $\begin{array}{l}\text { Facilitates } \\
\text { self-assessment } \\
\text { (reflection) }\end{array}$ & $\begin{array}{l}\text { Feedback gives students } \\
\text { opportunities to self-assess or } \\
\text { reflect. }\end{array}$ & $\begin{array}{l}\text { Self-assessment with rubrics. } \\
\text { Asking students to reflect on } \\
\text { practice and how it relates to future } \\
\text { goals/practice }\end{array}$ & $\begin{array}{l}\text { "How might this task be used in your } \\
\text { future profession? What skills are } \\
\text { transferred?" }\end{array}$ \\
\hline $\begin{array}{l}\text { Delivers high-quality } \\
\text { information }\end{array}$ & $\begin{array}{l}\text { Feedback should explicitly } \\
\text { inform students about the } \\
\text { quality of their learning } \\
\text { outcomes. }\end{array}$ & $\begin{array}{l}\text { Explicit information about } \\
\text { performance is required. Go beyond } \\
\text { generic statements and give } \\
\text { students clear areas on which to } \\
\text { improve. }\end{array}$ & $\begin{array}{l}\text { "I really like how you provided a } \\
\text { detailed description of the learning } \\
\text { environment. You took less time to } \\
\text { explain to your learners. Remember to } \\
\text { include the age, grade level, and } \\
\text { accommodations." }\end{array}$ \\
\hline $\begin{array}{l}\text { Encourages teacher } \\
\text { and peer dialogue }\end{array}$ & $\begin{array}{l}\text { Teacher-student and } \\
\text { peer-student interactions are } \\
\text { promoted with feedback. }\end{array}$ & $\begin{array}{l}\text { Provide students with opportunities } \\
\text { to clarify content and performance } \\
\text { in and outside of the class. } \\
\text { Technology tools are helpful in } \\
\text { interacting across time and space. }\end{array}$ & $\begin{array}{l}\text { "I see that you are not understanding } \\
\text { the topic. What is specifically causing } \\
\text { you confusion? Let's meet to discuss } \\
\text { this." }\end{array}$ \\
\hline $\begin{array}{l}\text { Encourages positive } \\
\text { motivational beliefs }\end{array}$ & $\begin{array}{l}\text { Feedback should provide } \\
\text { opportunities to increase } \\
\text { students' motivation and } \\
\text { self-efficacy. }\end{array}$ & $\begin{array}{l}\text { Feedback should not always be } \\
\text { critical. Provide comments that } \\
\text { point out when exceptional work } \\
\text { has been completed. This type of } \\
\text { feedback can be used as a model to } \\
\text { students in their future work. }\end{array}$ & $\begin{array}{l}\text { "Well done! I can see that you have } \\
\text { done a nice job clearly explaining the } \\
\text { topic and providing detailed } \\
\text { examples." }\end{array}$ \\
\hline $\begin{array}{l}\text { Closes gap in } \\
\text { learning }\end{array}$ & $\begin{array}{l}\text { Feedback delivers important } \\
\text { information regarding desired } \\
\text { learning, perceived learning, } \\
\text { and affords opportunities to } \\
\text { decrease that gap. }\end{array}$ & $\begin{array}{l}\text { Communicating goals and } \\
\text { objectives to students in } \\
\text { conjunction with feedback give } \\
\text { students information about where } \\
\text { they stand regarding the learning } \\
\text { process and if they need to make an } \\
\text { adjustment to meet those goals. }\end{array}$ & $\begin{array}{l}\text { "In this task, you should have defined } \\
\text { the topic and provide examples- you } \\
\text { only defined the key words." }\end{array}$ \\
\hline $\begin{array}{l}\text { Helps inform } \\
\text { teaching }\end{array}$ & $\begin{array}{l}\text { The process of providing } \\
\text { feedback and observing how } \\
\text { students apply that feedback } \\
\text { gives instructors valuable } \\
\text { information regarding their } \\
\text { teaching and learning methods } \\
\text { and strategies. }\end{array}$ & $\begin{array}{l}\text { Use student feedback as a way to } \\
\text { inform your instructional methods } \\
\text { and strategies. If many students are } \\
\text { unsure of something, reteach using } \\
\text { a different approach or set of tools. }\end{array}$ & $\begin{array}{l}\text { "Thank you for sharing your } \\
\text { frustrations. Next time I will try to } \\
\text { provide more visuals." }\end{array}$ \\
\hline
\end{tabular}




\subsection{Optimal Uses}

\subsubsection{Clarify}

Feedback helps to clarify what good performance is and communicates the goals, criteria, and expectations of the task. Nicol and Macfarlane-Dick (2006) emphasize the need for instructors and students to share a common understanding regarding the task. Definitions, concepts, and requirements need to be established and communicated in a way that students understand. Instructors might consider communicating expectations through various media forms (e.g., visual, oral, and written). Technologies can help instructors clarify performance requirements. For example, Digital badge systems give students various competencies and criteria within a single view. Students can then review material, submit tasks, and review assessment all in one place.

\subsubsection{Identify Gaps}

Feedback gives students opportunities to self-assess or reflect. Identifying gaps in expectations and actual learning gives students an opportunity to reflect on the strategies they use for learning, how they receive feedback, and how they apply that feedback. In doing the former, students reflect on the instructional content, instructional methods and student-teacher interactions that have or have not taken place. Instructors can make feedback a mutual process where they not only give feedback to students but ask students to contribute to the type of feedback they receive. Student-directed feedback is often overlooked and is desired by the student (Carless, 2006). Implementing opportunities for students to think about their work and how it might apply to their future profession is one-way educators can use this principle. Additionally, providing students with rubrics and requiring self-assessment could possibly identify gaps in their knowledge.

\subsubsection{Information}

Feedback should explicitly inform students about the quality of their learning outcomes. Feedback provided by instructors should be explicit and relate directly to goals, criteria, and expectations. While generic feedback might provide a positive comment to a student, it does not give enough information to where the student can then apply feedback. Being specific will help the student clear up any misconceptions, recognize areas of strength and weakness, and provide direction for next steps (Guskey, 2007). Nicol and Macfarlane - Dick (2006) define "quality external feedback [as] information that helps students troubleshoot their own performance and self-correct; that is, it helps students take action to reduce the discrepancy between their intentions and the resulting effects" (p. 9).

\subsubsection{Reflection}

Teacher-student and peer-student interactions are promoted within feedback. While feedback provided by the teacher is essential, another way for students to receive and learn how to provide feedback is through peer-assessment. In one study, researchers examined peer feedback within online instruction (Ertmer et al., 2007) Specifically, the authors examined the impact peer feedback had on the quality of online discussion postings. Findings resulted in students having greater abilities in providing feedback and increased the value of the process.

Not only does peer feedback provide students with increased opportunities to learn from the process, but it is also equally important to devote time to cultivating the teacher-student relationship. This principle directly relates to Chickering and Gamson's $(1987,1989)$ principle of student-teacher interaction. Various technologies give instructors choice in how and when they interact with students. When class ends, the student-teacher interaction doesn't have to stop. Instructors can provide multiple opportunities to clarify content and performance outside of class.

\subsubsection{Motivation}

Feedback should provide opportunities to increase students' motivation and self-efficacy. Instructor feedback must include a balanced representation of positive and critical comments. When exceptional work is completed, students need to be informed of their achievements. These areas are places where students can look to as models to inform their future work. Giving students multiple opportunities to resubmit and make changes to drafts makes the assessment process more motivational (Nicol \& Macfarlane - Dick, 2006).

\section{Implications}

Feedback delivers important information regarding desired learning and perceived learning and affords opportunities to decrease that gap. Nicol and Macfarlane - Dick (2006) write, "In higher education, most students have little opportunity to apply the feedback they receive to close the performance gap especially in the case of planned assignments" (p. 13). Students are often presented with feedback in response to an assignment, 
and then move on to a new topic without having opportunities to deepen their learning (Lynch et al., 2012), clear up misconceptions, or reflect on previous learning. Digital badge learning environments may be the answer to this issue. Consistent with the studies performed by the authors $(2019,2020)$, pairing digital badges with mastery learning was mutually beneficial to both the student and instructors. Furthermore, benefits to using digital badges to manage increased submissions and feedback resulted in the ability of the instructor to provide prompt feedback, extend the learning task with various resources, utilize a variety of instructional methods (e.g., video and audio), and model instructional approaches to aid in the student to teacher transition.

When using digital badges, instructors provide students tasks with guidelines and objectives clearly defined (aligned to mastery learning principles) and provide specific feedback directly related to these criteria. Additionally, they can then allow for multiple submissions, therefore permitting and affording students opportunities to fully master the concepts before moving on. These technologies mitigate this issue and provide opportunities to deepen their learning (Lynch, McNamara, \& Seery, 2012).

When learners have opportunities to fill gaps in their learning, there is potential impact to learning performance. Newby and Cheng (2019) compared digital badge contexts with traditional learning environments and found students reported increases in perceived confidence in technology integration skills, but also exhibited higher levels of course tasks and overall grade achievement. Additionally, using digital badges offers learners personalization and opportunities to facilitate goals and self-regulate their learning (Cheng, Watson, \& Newby, 2018).

Badges are designed to not only communicate mastery of skills and knowledge, but also communicate the requirements of the task through a data-rich digital context. Digital badges further communicate to the learner their mastery longitudinally, which is especially important amongst educators that are life-long learners (Fanfarelli, Vie, \& McDaniel, 2015). Various authors have explored the role of digital badges within education and offer a myriad of strategies, platforms, and considerations when integrating these approaches (Besser, 2018; Grant, 2016), opportunities for professional development (Zhang \& West, 2020), and examples of how various institutions are integrating their use (Farmer \& West, 2016).

\section{Conclusion}

Instructional feedback is an important skill for educators to master and is a crucial component of integrating Mastery Learning approaches. Using emerging technologies like digital badges provides opportunities to internalize the feedback in various ways (Hepplestone \& Chikwa, 2014). Assessment occurs multiple times throughout a task, and instructors need to be well-versed in how to provide rich, quality feedback (Orsmond, Merry, \& Reiling, 2005), where students learn how to receive and apply it. Integrating any type of technology poses potential challenges, however integrating digital badges has the potential to develop deeper learning in learners through leveraging instructional feedback and mastery learning approaches. The potential outcomes make this a meaningful option for educators.

\section{References}

Abramovich, S., Schunn, C., \& Higashi, R. M. (2013). Are badges useful in education? It depends upon the type of badge and expertise of learner. Educational Technology Research and Development, 61, 217-232. https://doi.org/10.1007/s11423-013-9289-2

Atkinson, R. C. (1974). Adaptive instructional systems: Some attempts to optimize the learning process. Stanford University, Institute for Mathematical Studies in the Social Sciences.

Azevedo, R., \& Bernard, R. M. (1995). A meta-analysis of the effects of feedback in computer-based instruction. Journal of Educational Computing Research, 13(2), 111-127. https://doi.org/10.2190/9LMD-3U28-3A0G-FTQT

Balzer, W. K., Doherty, M. E., \& O’Connor, R. (1989). Effects of cognitive feedback on performance. Psychological Bulletin, 106(3), 410. https://doi.org/10.1037/0033-2909.106.3.410

Bangert, A. W. (2004). The seven principles of good practice: A framework for evaluating on-line teaching. The Internet and Higher Education, 7(3), 217-232. https://doi.org/10.1016/j.iheduc.2004.06.003

Bergmann, J., \& Sams, A. (2012). Flip your classroom. Eugene, OR: International Society for Technology in Education.

Besser, E. D. (2018). Digital badges and the K-12 Classroom: A Guide for Teachers. South Carolina Association of Teacher Educators.

Besser, E. D., \& Newby, T. J. (2019). Exploring the role of feedback and its impact within a digital badge system 
from student perspectives. TechTrends, 63(4), 485-495. https://doi.org/10.1007/s11528-019-00386-2

Besser, E. D., \& Newby, T. J. (2020). Feedback in a Digital Badge Learning Experience: Considering the Instructor's Experience. TechTrends. https://doi.org/10.1007/s11528-020-00485-5

Black, P., \& Wiliam, D. (1998). Assessment and classroom learning. Assessment in Education, 5(1), 7-74. https://doi.org/10.1080/0969595980050102

Bloom, B. S. (1968). Learning for Mastery. Instruction and Curriculum. Regional Education Laboratory for the Carolinas and Virginia, Topical Papers and Reprints, Number 1. Evaluation Comment, 1(2), n2.

Bloom, B. S. (1976). Human characteristics and school learning. New York: New York: McGraw-Hill.

Bowen, K., \& Thomas, A. (2014). Badges: A Common Currency for Learning. Change, 46(1), 21-25. https://doi.org/10.1080/00091383.2014.867206

Bramante, F., \& Colby, R. (2012). Off the clock: Moving education from time to competency. Corwin Press. https://doi.org/10.4135/9781506335292

Brigham Young University: Instructional Psychology. (n.d.). How we use badges. Retrieved November 27, 2014, from http://iptedtec.org/what-are-badges/

Buckingham, J. (2014). Open Digital badges for the Uninitiated. TESL-EJ, 18(1), 1-11.

Buell, C. (2013). Using Badges to Quantify Learning Outcomes at UC Davis. Retrieved December 10, 2014, from http://edcetera.rafter.com/using-badges-to-quantify-learning-outcomes-at-uc-davis/

Butler, D. L., \& Winne, P. H. (1995). Feedback and self-regulated learning: A theoretical synthesis. Review of Educational Research, 65(3), 245-281. https://doi.org/10.3102/00346543065003245

Carless, D. (2006). Differing perceptions in the feedback process. Studies in Higher Education, 31(2), 219-233. https://doi.org/10.1080/03075070600572132

Cheng, Z., Watson, S. L., \& Newby, T. J. (2018). Goal Setting and Open digital badges in Higher Education. TechTrends, 62, 190-196. https://doi.org/10.1007/s11528-018-0249-x

Chickering, A. W., \& Ehrmann, S. C. (1996). Implementing the seven principles: Technology as a lever. AAHE Bulletin, 49, 3-6.

Chickering, A. W., \& Gamson, Z. F. (1987). Seven principles for good practice in undergraduate education. AAHE Bulletin, 3, 7.

Chickering, A. W., \& Gamson, Z. F. (1989). Seven principles for good practice in undergraduate education. Biochemical Education, 17(3), 140-141. https://doi.org/10.1016/0307-4412(89)90094-0

CS2N. (n.d.). CS2N Badges. Retrieved January 29, 2015, from https://www.cs2n.org/teachers/badges

Davidson-Shivers, G. V. (2009). Frequency and types of instructor interactions in online instruction. Journal of Interactive Online Learning, 8(1), 23-40.

Devedžić, V., \& Jovanović, J. (2015). Developing Open Badges: a comprehensive approach. Educational Technology Research and Development, 63, 603-620. https://doi.org/10.1007/s11423-015-9388-3

Ertmer, P. A., Richardson, J. C., Belland, B., Camin, D., Connolly, P., Coulthard, G., \& Mong, C. (2007). Using Peer Feedback to Enhance the Quality of Student Online Postings: An Exploratory Study. Journal of Computer-Mediated Communication, 12(2), 412-433. https://doi.org/10.1111/j.1083-6101.2007.00331.x

Fain, P. (2014). Badging from Within. Retrieved January 27, 2015, from https://www.insidehighered.com/news/2014/01/03/uc-daviss-groundbreaking-digital-badge-system-new-sus tainable-agriculture-program

Fanfarelli, J., Vie, S., \& McDaniel, R. (2015). Understanding digital badges through feedback, reward, and narrative: a multidisciplinary approach to building better badges in social environments. Communication Design Quarterly Review, 3(3), 56-60. https://doi.org/10.1145/2792989.2792998

Farmer, T., \& West, R. E. (2016). Opportunities and challenges with digital open badges. Educational Technology, 45-48.

Gallagher, C. W. (2014). Disrupting the Game-Changer: Remembering the History of Competency-Based Education. Change. The Magazine of Higher Learning, 46(6), 16-23. https://doi.org/10.1080/00091383.2014.969177 
Gamrat, C., Zimmerman, H. T., Dudek, J., \& Peck, K. (2014). Personalized workplace learning: An exploratory study on digital badging within a teacher professional development program. British Journal of Educational Technology, 45(6), 1136-1148. https://doi.org/10.1111/bjet.12200

Getzlaf, B., Perry, B., Toffner, G., Lamarche, K., \& Edwards, M. (2009). Effective Instructor Feedback: Perceptions of Online Graduate Students. Journal of Educators Online, 6(2), n2. https://doi.org/10.9743/JEO.2009.2.1

Gibson, D., Ostashewski, N., Flintoff, K., Grant, S., \& Knight, E. (2013). Digital badges in education. Education and Information Technologies, 20(2), 403-410. https://doi.org/10.1007/s10639-013-9291-7

Glover, I., \& Latif, F. (2013). Investigating perceptions and potential of open badges in formal higher education. Paper presented at the World Conference on Educational Multimedia, Hypermedia and Telecommunications.

Graham, C., Cagiltay, K., Lim, B., Craner, J., \& Duffy, T. M. (2001). Seven principles of effective teaching: A practical lens for evaluating online courses. The Technology Source, 30(5), 50.

Grant, S. (2016). Building Collective Belief in Badges: Designing Trust Networks. In Foundation of digital badges and Micro-Credentials (pp. 97-114). Springer, Cham. https://doi.org/10.1007/978-3-319-15425-1_6

Guskey, T. R. (2003). How classroom assessments improve learning. Educational Leadership, 60(5), 6-11.

Guskey, T. R. (2007). Closing achievement gaps: Revisiting Benjamin S. Bloom's "Learning for Mastery". Journal of Advanced Academics, 19(1), 8-31. https://doi.org/10.4219/jaa-2007-704

Hepplestone, S., \& Chikwa, G. (2014). Understanding how students process and use feedback to support their learning. Practitioner Research in Higher Education, 8(1), 41-53.

Higgins, R., Hartley, P., \& Skelton, A. (2002). The conscientious consumer: reconsidering the role of assessment feedback in student learning. Studies in Higher Education, 27(1), 53-64. https://doi.org/10.1080/03075070120099368

Hmelo-Silver, C. E., \& Barrows, H. S. (2006). Goals and strategies of a problem-based learning facilitator. Interdisciplinary Journal of Problem-Based Learning, 1(1), 4. https://doi.org/10.7771/1541-5015.1004

Johnstone, S. M., \& Soares, L. (2014). Principles for developing competency-based education programs. Change, 46(2), 12-19. https://doi.org/10.1080/00091383.2014.896705

Kluger, A. N., \& DeNisi, A. (1996). The effects of feedback interventions on performance: a historical review, a meta-analysis, and a preliminary feedback intervention theory. Psychological Bulletin, 119(2), 254. https://doi.org/10.1037/0033-2909.119.2.254

Knight, E., Casilli, C., Lee, S., Goligoski, E., McAvoy, C., Brennan, B., \& Forester, J. (2014). Badges. Retrieved September 15, 2015, from https://wiki.mozilla.org/Badges

Kulhavy, R. W. (1977). Feedback in written instruction. Review of Educational Research, 211-232. https://doi.org/10.3102/00346543047002211

Light, D., \& Pierson, E. (2014). Increasing Student Engagement in Math: The use of Khan Academy in Chilean Classrooms. International Journal of Education and Development Using ICT, 10(2), 103-119.

Lin, C.-H., Liu, E. Z.-F., Chen, Y.-L., Liou, P.-Y., Chang, M., Wu, C.-H., \& Yuan, S.-M. (2013). Game-Based Remedial Instruction in Mastery Learning for Upper-Primary School Students. Educational Technology \& Society, 16(2), 271-281.

Lynch, R., McNamara, P. M., \& Seery, N. (2012). Promoting deep learning in a teacher education programme through self- and peer-assessment and feedback. European Journal of Teacher Education, 35(2), 179-197. https://doi.org/10.1080/02619768.2011.643396

MacArthur Foundation. (2014). Digital badges. Retrieved December 6, 2014, from http://www.macfound.org/programs/digital-badges/

MacArthur Foundation. (n.d.). DePaul University. Retrieved January 27, 2015, from $\mathrm{http} / / / \mathrm{www}$.macfound.org/grantees/252/

Martyn, M. (2007). Clickers in the classroom: An active learning approach. Educause Quarterly, 30(2), 71.

Mehta, N. B., Hull, A. L., Young, J. B., \& Stoller, J. K. (2013). Just imagine: new paradigms for medical education. Academic Medicine, 88(10), 1418-1423. https://doi.org/10.1097/ACM.0b013e3182a36a07 
Mettler, E., Massey, C., \& Kellman, P. J. (2011). Improving adaptive learning technology through the use of response times. Paper presented at the Proceedings of the 33rd Annual Conference of the Cognitive Science Society. Boston, MA: Cognitive Science Society.

Mozilla. (n.d.). Mozilla Open Badges. Retrieved June 12, 2014, from http://openbadges.org/about/

Newby, T. J., \& Cheng, Z. (2019). Instructional digital badges: Effective learning tools. Educational Technology Research and Development. https://doi.org/10.1007/s11423-019-09719-7

Nicol, D. J., \& Macfarlane - Dick, D. (2006). Formative assessment and self - regulated learning: a model and seven principles of good feedback practice. Studies in Higher Education, 31(2), 199-218. https://doi.org/10.1080/03075070600572090

Orsmond, P., Merry, S., \& Reiling, K. (2005). Biology students' utilization of tutors' formative feedback: A qualitative interview study. Assessment \& Evaluation in Higher Education, 30(4), 369-386. https://doi.org/10.1080/02602930500099177

Ostashewski, N., \& Reid, D. (2015). A History and Frameworks of Digital badges in Education Gamification in Education and Business (pp. 187-200). Springer International Publishing. https://doi.org/10.1007/978-3-319-10208-5_10

Pintrich, P. R., \& Zusho, A. (2007). Student motivation and self-regulated learning in the college classroom the scholarship of teaching and learning in higher education: An evidence-based perspective (pp. 731-810). Springer International Publishing. https://doi.org/10.1007/1-4020-5742-3_16

Pokorny, H., \& Pickford, P. (2010). Complexity, cues, and relationships: Student perceptions of feedback. Active Learning in Higher Education, 11(1), 21-30. https://doi.org/10.1177/1469787409355872

Price, M., Handley, K., Millar, J., \& O’Donovan, B. (2010). Feedback: all that effort, but what is the effect? Assessment \& Evaluation in Higher Education, 35(3), 277-289. https://doi.org/10.1080/02602930903541007

Ramaprasad, A. (1983). On the definition of feedback. Behavioral Science, 28(1), 4-13. https://doi.org/10.1002/bs.3830280103

Randall, D. L., Harrison, J. B., \& West, R. E. (2013). Giving credit where credit is due: designing open badges for a technology integration course. TechTrends, 57(6), 88-95. https://doi.org/10.1007/s11528-013-0706-5

Reigeluth, C. M., \& Karnopp, J. R. (2013). Reinventing schools: It's time to break the mold. New York: Rowman \& Littlefield Education.

Seton Hall University's Teaching, L., \& Technology, C. (n.d.). Stillman Passport. Retrieved December 10, 2014, from https://tltc.shu.edu/badges/stillmanPassport.php

Skills, P. F. S. C. (2009). P21 Framework Definitions. Retrieved July 17, 2013, from http://www.p21.org/overview/skills-framework

Slavin, R. E., \& Karweit, N. L. (1984). Mastery learning and student teams: A factorial experiment in urban general mathematics classes. American Educational Research Journal, 21(4), 725-736. https://doi.org/10.3102/00028312021004725

Squires, D. (2012). Curriculum Alignment Research Suggests That Alignment Can Improve Student Achievement. Clearing House, 85(4), 129-135. https://doi.org/10.1080/00098655.2012.657723

Sturgis, C., Patrick, S., \& Pittenger, L. (2011). It's Not a Matter of Time: Highlights from the 2011 Competency-Based Summit. International Association for K-12 Online Learning.

Tally, S. (2012). Digital badges show students' skills along with degree. Retrieved January 27, 2015, from http://www.purdue.edu/newsroom/releases/2012/Q3/digital-badges-show-students-skills-along-with-degree. html

Thurmond, V. A., Wambach, K., Connors, H. R., \& Frey, B. B. (2002). Evaluation of student satisfaction: Determining the impact of a web-based environment by controlling for student characteristics. The American Journal of Distance Education, 16(3), 169-190. https://doi.org/10.1207/S15389286AJDE1603_4

Tucker, S. A. (1993). Evaluation as feedback in instructional technology: The role of feedback in program evaluation (pp. 301-342). Interactive Instruction and Feedback. Englewood Cliffs, NJ: Educational Technology Publications.

Weise, M. R. (2014). Is There any Difference between Competency-Based Education and Mastery-Based 
Learning? Retrieved from Competency Works: Learning from the Cutting Edge website: http://www.competencyworks.org/higher-education-2/is-there-any-difference-between-competency-based-e ducation-and-mastery-based-learning/

Wonder-McDowell, C., Reutzel, D. R., \& Smith, J. A. (2011). Does Instructional Alignment Matter? The Elementary School Journal, 112(2), 259-279. https://doi.org/10.1086/661524

Yang, M., \& Carless, D. (2013). The feedback triangle and the enhancement of dialogic feedback processes. Teaching in Higher Education, 18(3), 285-297. https://doi.org/10.1080/13562517.2012.719154

Yorke, M. (2003). Formative assessment in higher education: Moves towards theory and the enhancement of pedagogic practice. Higher Education, 45(4), 477-501. https://doi.org/10.1023/A:1023967026413

Zhang, J., \& West, R. E. (2020). Designing Microlearning Instruction for Professional Development Through a Competency Based Approach. TechTrends, 64, 310-318. https://doi.org/10.1007/s11528-019-00449-4

\section{Copyrights}

Copyright for this article is retained by the author, with first publication rights granted to the journal.

This is an open-access article distributed under the terms and conditions of the Creative Commons Attribution license (http://creativecommons.org/licenses/by/4.0/). 